\title{
Systems biology strategy reveals PKC $\delta$ is key for sensitizing TRAIL-resistant human fibrosarcoma
}

\author{
Kentaro Hayashi ${ }^{1,2}$, Sho Tabata ${ }^{1,2}$, Vincent Piras ${ }^{1,2}$, Masaru Tomita ${ }^{1,2}$ and Kumar Selvarajoo ${ }^{1,2} *$ \\ 1 Institute for Advanced Biosciences, Keio University, Tsuruoka, Japan \\ 2 Systems Biology Program, Graduate School of Media and Governance, Keio University, Fujisawa, Japan
}

\section{Edited by:}

Fabrizio Mattei, Istituto Superiore di

Sanità, Italy

\section{Reviewed by:}

Frank Kruyt, University Medical Center Groningen, Netherlands

Pablo Meyer, International Business Machines, USA

\section{*Correspondence:}

Kumar Selvarajoo, Institute for

Advanced Biosciences, Keio

University, 14-1 Baba-cho, Tsuruoka,

Yamagata, Japan

e-mail:kumar@ttck.keio.ac.jp

\begin{abstract}
Cancer cells are highly variable and largely resistant to therapeutic intervention. Recently, the use of the tumor necrosis factor related apoptosis-inducing ligand (TRAIL) induced treatment is gaining momentum due to TRAIL's ability to specifically target cancers with limited effect on normal cells. Nevertheless, several malignant cancer types still remain non-sensitive to TRAIL. Previously, we developed a dynamic computational model, based on perturbation-response differential equations approach, and predicted protein kinase $\mathrm{C}$ (PKC) as the most effective target, with over 95\% capacity to kill human fibrosarcoma (HT1080) in TRAIL stimulation (1). Here, to validate the model prediction, which has significant implications for cancer treatment, we conducted experiments on two TRAIL-resistant cancer cell lines (HT1080 and HT29). Using PKC inhibitor bisindolylmaleimide I, we demonstrated that cell viability is significantly impaired with over $95 \%$ death of both cancer types, in consistency with our previous model. Next, we measured caspase-3, Poly (ADP-ribose) polymerase (PARP), p38, and JNK activations in HT1080, and confirmed cell death occurs through apoptosis with significant increment in caspase-3 and PARP activations. Finally, to identify a crucial PKC isoform, from 10 known members, we analyzed each isoform mRNA expressions in HT1080 cells and shortlisted the highest 4 for further siRNA knock-down (KD) experiments. From these KDs, PKC $\delta$ produced the most cancer cell death in conjunction with TRAIL. Overall, our approach combining model predictions with experimental validation holds promise for systems biology based cancer therapy.
\end{abstract}

Keywords:TRAIL, protein kinase C, signaling pathway, cancer, apoptosis, cell dynamics, computational model

\section{INTRODUCTION}

Numerous recent studies have revealed the close link between inflammation and cancer. First, various types of immune cells, which support tumor growth progression, are found within the tumor microenvironment $(2,3)$. Second, the vicinity of cancer cells displays increased proinflammatory activity, through the detection of elevated levels of major cytokines such as the tumor necrosis factor (TNF) $(4,5)$. One notable cytokine found within the tumor microenvironment is the TNF related apoptosis-inducing ligand or TRAIL, which has been shown to induce apoptosis in certain types of malignant cancers with no significant effect on normal cells $(6,7)$. The findings have led to a major stride in the ongoing research aimed at optimizing TRAIL-induced cancer therapy (8, 9). Despite some success, TRAIL-based therapies still show dismal results for several types of cancers such as the breast cancer, neuroblastoma, adenocarcinoma, and glioma (10-13).

Computational modeling approaches are becoming increasing useful for interpreting complex dynamical cellular responses (14-21). Previously, to understand the mechanism for TRAILresistance in cancer, we developed a dynamic computational model of TRAIL signaling, from extracellular receptor activation to downstream intracellular activation of cell survival (MAP kinases and $\mathrm{I} \kappa \mathrm{B}$ ) and apoptosis (caspases-8 and -3 ) pathways (1). Our model was based on perturbation-response approach utilizing first-order response equations $(1,22-29)$, which was shown to successfully simulate the temporal experimental profiles I $\mathrm{KB}$, JNK, p38, caspase- 8 and -3 in wildtype, and four (FADD, RIP1, TRAF2, and caspase-8) knock-down (KD) conditions for human fibrosarcoma (30). We, subsequently, predicted targeting a novel molecule interacting with p62 in the model would significantly increase caspase-3 activation and enhance cancer apoptosis to TRAIL stimulation. Further protein-protein interaction (PPI) database analysis suggested that the novel molecule is most probably a protein kinase C (PKC) family member.

Here, we tested the model prediction by experimentally verifying whether targeting PKC will enhance apoptosis in TRAILresistant cancer cell lines. Experiments were performed on TRAILinduced human fibrosarcoma (HT1080) and human colon adenocarcinoma (HT29) cells, and the cell viability was compared with control normal fibroblasts (TIG-1 and MRC-5). Moreover, to investigate the intracellular mechanisms for resultant cell viability, we measured time-course activation levels of caspase-3, PARP, p38, and JNK. Subsequently, we analyzed the expressions of each PKC isoform member in HT1080 cells. To identify a crucial target member for enhanced cancer apoptosis, we prepared relevant siRNA KD experiments. In summary, our study investigates (i) whether the model prediction of PKC suppression will enhance cancer cell death is true, and (ii) whether computational modeling using perturbation-response approach is valuable for biological research focusing on cancer treatment. 


\section{MATERIALS AND METHODS REAGENTS AND CELL CULTURE}

Recombinant human TRAIL was purchased from Peprotech. Bisindolylmaleimide I (BIM-I) was purchased from Merck Millipore. Human fibrosarcoma cell lines (HT1080), human embryo fibroblasts (TIG-1), and human colorectal adenocarcinoma cells (HT29) were obtained from Japanese Collection of Research Bioresources (JCRB) cell bank. Human fetal lung fibroblasts (MRC-5) were obtained from American Type Culture Collection (ATCC). HT1080, TIG-1, HT29, and MRC-5 were grown in DMEM (Nissui Seiyaku Co.) containing 10\% calf serum, $100 \mathrm{U} / \mathrm{mL}$ of penicillin, Streptomycin $100 \mu \mathrm{g} / \mathrm{ml}$ and Amphotericin $\mathrm{B} 0.25 \mu \mathrm{g} / \mathrm{ml}$ at $37^{\circ} \mathrm{C}$ in a $5 \% \mathrm{CO}_{2}$ humidified atmosphere.

\section{CELL VIABILITY ASSAY}

The cell viability was measured by 3-(4,5-dimethylthiazol-2-yl)2,5-diphenyltetrazolium bromide (MTT) assay and trypan blue exclusion. MTT assay: cells $\left(10 \times 10^{4}\right)$ were inoculated in each well and incubated for $24 \mathrm{~h}$. Thereafter, $50 \mu \mathrm{L}$ of MTT $(2 \mathrm{mg} / \mathrm{mL}$ in PBS) was added to each well and the plates were incubated for a further $2 \mathrm{~h}$. The resultant formazan was dissolved with $100 \mu \mathrm{L}$ of dimethyl sulfoxide (DMSO) after aspiration of culture medium. Plates were placed on a plate shaker for $1 \mathrm{~min}$ and then read immediately at $570 \mathrm{~nm}$ using TECAN microplate reader with Magellan software (Männedorf, Switzerland). Trypan blue exclusion: cells were detached with $1 \mathrm{~mL}$ of trypsin and suspended in DMEM. After staining with trypan blue, viable cells were counted using microscopy $(n=3)$. The percentage of trypan blue exclusive viable cells was determined as a percentage of the total number of cells.

\section{WESTERN BLOT ANALYSIS}

Anti-PARP, anti-phospho-p38, and anti- $\beta$-actin antibodies were purchased from Cell Signaling Technology. Proteins were extracted from the cell lines using radioimmunoprecipitation assay (RIPA) buffer according to the manufacturer's instructions. Next, their concentrations were measured by Bradford protein assay. Equal amounts of protein were loaded in each well and separated by $10 \%$ sodium dodecyl sulfate-polyacrylamide gel electrophoresis (SDSPAGE), which was subsequently transferred onto a polyvinylidene difluoride (PVDF) membrane. The membrane was blocked for $1 \mathrm{~h}$ with 5\% BSA in TBST on the shaker at room temperature. The membrane was placed on PARP and p-p38 antibody diluted at a $1: 1000$ proportion in diluent buffer [5\% (w/v) BSA and $0.1 \%$ Tween 20 in TBS] and incubated overnight at $4^{\circ} \mathrm{C}$ on the shaker. The membrane was washed three times in TBS as above and incubated with secondary antibody diluted at a 1:10000 proportion for $1 \mathrm{~h}$ on the shaker at room temperature. The membrane was again washed three times for $5 \mathrm{~min}$ each time as above and finally the results were generated by using an enhanced chemiluminescence (ECL) Western blotting kit.

\section{ENZYME LINKED IMMUNOSORBENT ASSAYS OF CLEAVED CASPASE-3 AND PHOSPHORYLATED JNK}

Cleaved caspase- 3 and phosphorylated JNK concentrations were measured by ELISA Duo Sets IC Kit (R\&D Systems) following the instructions of the manufacturer.

\section{TRANSFECTION}

siRNA duplexes were purchased from Sigma. The transfection of classic PKCs (PKC $\alpha, P K C \beta, P K C \gamma)$, the novel PKCs (PKC $\delta$, PKC $\varepsilon, P K C \eta, P K C \mu, P K C \theta)$, and the atypical PKCs (PKC, PKCı) and scrambled siRNA were carried out using Lipofectamine 2000 according to the manufacturer's instructions (Invitrogen).

\section{QUANTITATIVE REAL-TIME PCR ANALYSIS}

Total cellular RNA was extracted from cells using the TRIzol reagent according to the manufacturer's instructions (Invitrogen). One microgram of RNA was reverse-transcribed using a firststrand cDNA synthesis kit (ReverTra Ace $\alpha$; Toyobo). Quantitative real-time PCR (qRT-PCR) was performed using SYBR premix Ex Taq (Takara) on the Applied Biosystems StepOnePlus ${ }^{\mathrm{TM}}$ according to the technical brochure of the company. qRT-PCR primers used in this study are listed in Table 1. Quantitative measurements were determined using the $\Delta \Delta \mathrm{Ct}$ method and expressions of GAPDH gene for PKC genes and RPL27 gene for rela, mtor, bcl2, bax, cytoc, and jun were used as the internal control. Melt curve analyses of all qRT-PCR products were performed and shown to produce the sole DNA duplex.

\section{RESULTS}

\section{EFFECT OF PKC INHIBITOR IN TRAIL-RESISTANT HT1080 CELLS}

Based on our previous computational TRAIL model, the removal of PKC family members would enhance HT1080 cell death by $95 \%$ (1). Here, we investigated the actual experimental effect of PKC inhibition to HT1080 cells in TRAIL stimulation. HT1080 cells were stimulated with $1000 \mathrm{ng} / \mathrm{mL}$ of TRAIL in the presence or absence of $10 \mu \mathrm{M}$ of PKC inhibitor (31-33), BIM-I, pre-treatment and compared with unstimulated control with and without BIMI pre-treatment (Figure 1A). We observed, phenotypically, that HT1080 cell death was significantly increased in combinatorial treatment of TRAIL and BIM-I (Figure 1A, forth column), while control pre-treated with BIM-I did not induce any noticeable cell death (Figure 1A, second column).

Next, we investigated cell survival ratio using MTT assays for HT1080 cells pre-treated with BIM-I with increasing dosage $(0$, 3 , and $10 \mu \mathrm{M}$ ) for $30 \mathrm{~min}$ prior to increasing TRAIL stimulation $(0,100,200,400$, and $1000 \mathrm{ng} / \mathrm{mL})$ for $24 \mathrm{~h}$ (Figure 1B). Notably, from these experiments, it is clear that HT1080 cell death is almost unaffected with any dosage of BIM-I without TRAIL stimulation. However, when BIM-I was treated in the presence of TRAIL, the effect synergistically produced significant cell death, compared with TRAIL alone (Figure 1B). Remarkably, as predicted by our previous computational TRAIL model (1), the inhibition of PKC (with $10 \mu \mathrm{M}$ of BIM-I) resulted in about 99\% cell death for TRAIL stimulation (with $100 \mathrm{ng} / \mathrm{mL}$ or more) in HT1080 cells. We further investigated the cell viability of HT1080 with respect to stimulation time, and noticed that significant cell death occurs at $3 \mathrm{~h}$ and onward (Figure 1C).

Next, in addition to HT1080, we also investigated another TRAIL-resistant cancer cell type (HT29) and compared with normal fibroblasts (TIG-1 and MRC-5). Experiment-matched MTT assays revealed that both HT1080 and HT29 cell cultures treated with BIM-I were sensitized to TRAIL-induced cell death (approximately 99 and 95\% cell death, respectively), while normal TIG-1 
Table 1 | List of primer sequences for qRT-PCR

\begin{tabular}{|c|c|c|c|}
\hline Name & Species & Primer name & Sequence $\left(5^{\prime}-3^{\prime}\right)$ \\
\hline \multirow[t]{2}{*}{$P K C \alpha$} & Human & $P K C \alpha \_F$ & CCACACTAAATCCGCAGTGG \\
\hline & Human & $P K C \alpha \_R$ & CAGCTCCGAAACTCCAAAGGA \\
\hline \multirow[t]{2}{*}{$P K C \beta$} & Human & PKC $\beta \_F$ & TTGTGGACCTGAAGGCGAAC \\
\hline & Human & $P K C \beta \_R$ & CGGGTGAAAAATCGGTCGAAG \\
\hline \multirow[t]{2}{*}{$P K C \gamma$} & Human & $\mathrm{PKC} \gamma_{-} \mathrm{F}$ & GCTTGTAACTACCCCCTGGAAT \\
\hline & Human & $\mathrm{PKC} \gamma_{-} \mathrm{R}$ & GAAGCTGAAGTCGGAGATGTG \\
\hline \multirow[t]{2}{*}{$P K C \delta$} & Human & $\mathrm{PKC} \delta \_F$ & TGGTGGTTGGTGCGTTGTAG \\
\hline & Human & $\mathrm{PKC} \delta \_\mathrm{R}$ & ATAGGAGTTGAAGGCGATGCG \\
\hline \multirow[t]{2}{*}{$P K C \varepsilon$} & Human & $\mathrm{PKC} \varepsilon_{-} \mathrm{F}$ & CAAGCCACCCTTCAAACCAC \\
\hline & Human & $\mathrm{PKC} \varepsilon_{-} \mathrm{R}$ & CGTCCACAAGGGTGAGTACC \\
\hline \multirow[t]{2}{*}{$P K C \eta$} & Human & $\mathrm{PKC} \eta_{-} \mathrm{F}$ & GTGTCGTCCATAAACGCTGC \\
\hline & Human & $\mathrm{PKC} \eta_{-} \mathrm{R}$ & ATCCCGAACCTCTGTTCTGC \\
\hline \multirow[t]{2}{*}{$P K C \mu$} & Human & $\mathrm{PKC} \mu \_\mathrm{F}$ & GAGGACGCCAACAGAACCAT \\
\hline & Human & $\mathrm{PKC} \mu \_\mathrm{R}$ & CCTTGCTGGTGTAGTGGACC \\
\hline \multirow[t]{2}{*}{$P K C \theta$} & Human & PKC $\theta_{-} F$ & GCTGATTGGTCAGTCGCCTT \\
\hline & Human & PKC $\theta \_R$ & TCTTCTCAGGTTCTCGCACG \\
\hline \multirow[t]{2}{*}{$P K C \zeta$} & Human & $\mathrm{PKC} \zeta_{-} \mathrm{F}$ & CACATGCAGAGGCAGAGGAA \\
\hline & Human & $\mathrm{PKC \zeta} \mathrm{R}$ & GAGGACGTTGTCCAGCTTCA \\
\hline \multirow[t]{2}{*}{$P K C_{\imath}$} & Human & $\mathrm{PKCl} F \mathrm{~F}$ & GCCATCTGCACAGACCGAAT \\
\hline & Human & PKCı_R & TCCATGGGCATCACTGGTTC \\
\hline \multirow[t]{2}{*}{ rela } & Human & RelA_F & GTGGGGACTACGACCTGAATG \\
\hline & Human & RelA_R & AGATCTTGAGCTCGGCAGTG \\
\hline \multirow[t]{2}{*}{ mtor } & Human & mTOR_F & TCGCTGAAGTCACACAGACC \\
\hline & Human & mTOR_R & CTTTGGCATATGCTCGGCAC \\
\hline \multirow[t]{2}{*}{$b c / 2$} & Human & BCL2_F & AACATCGCCCTGTGGATGAC \\
\hline & Human & BCL2_R & TTCACTTGTGGCCCAGATAGG \\
\hline \multirow[t]{2}{*}{ bax } & Human & BAX_F & ACAGGGGCCCTTTTGCTTC \\
\hline & Human & BAX_R & CTTGGTGGACGCATCCTGAG \\
\hline \multirow[t]{2}{*}{ cytoc } & Human & Cytochorome c_F & AGCGGGAGTGTTCGTTGTG \\
\hline & Human & Cytochorome c_R & ССТСССTTTTCAACGGTGTG \\
\hline \multirow[t]{2}{*}{ jun } & Human & Jun_F & ACGGCGGTAAAGACCAGAAG \\
\hline & Human & Jun_R & CCAAGTTCAACAACCGGTGC \\
\hline \multirow[t]{2}{*}{ GAPDH } & Human & GAPDH_F & GTCAACGGATTTGGTCGTAT \\
\hline & Human & GAPDH_R & TGGTGATGGGATTTCCATTG \\
\hline \multirow[t]{2}{*}{ RPL27 } & Human & RPL27_F & CTGTCGTCAATAAGGATGTCT \\
\hline & Human & RPL27_R & CTTGTTCTTGCCTGTCTTGT \\
\hline
\end{tabular}

and MRC-5 largely survived (Figures 1D,E). These results indicate that PKC inhibitor, BIM-I, has specific ability to enhance cell death in TRAIL-resistant cancer cells while having little effect on normal cells.

\section{TREATMENT OF PKC INHIBITOR WITH TRAIL ENHANCES CELL DEATH THROUGH APOPTOSIS}

The experimental results, so far, are consistent with our previous model simulations. To further scrutinize the result, that is, to explore the origins of cell death, we performed analysis to observe intracellular markers prior to cell death. According to our model, PKC inhibition causes enhancement of apoptotic pathways through signaling flux redistribution (SFR) $(1,22)$. To check whether apoptosis is increased in TRAIL stimulated and BIM-I treated HT1080 cells, we measured PARP cleavage and p38 phosphorylation using western blotting assays, and caspase-3 activation and JNK phosphorylation using enzyme linked immunosorbent assays (ELISAs) (Figure 2).

Consistent with the prediction of computational model, we observed substantial induction of PARP and caspase-3 cleavage, indicating increased apoptosis in HT1080 cells treated with BIM-I when compared with untreated cells in TRAIL stimulation (Figure 2A, top panel and Figure 2B, right panel). We further noticed enhanced $\mathrm{p} 38$ activation and low activity of JNK in TRAILstimulated cells treated with BIM-I (Figure 2A, middle panel and Figure 2B, left panel), in agreement with our model predictions for SFR at p62 pathway junction (1) (Figure 2C). Note that the housekeeping protein $\beta$-actin remained almost unaffected in the western blots. These results clearly demonstrate that BIM-I is a potential therapeutic target for HT1080 treatment.

To examine the expression levels of appropriate genes in TRAIL-stimulated HT1080, with and without BIM-I, we performed qRT-PCR experiments for several survival and apoptotic genes (rela, mtor, bcl2, bax, cytoc, and jun) at 0, 20, 40, 60, 120, and $180 \mathrm{~min}$ (Figure 3). Except for jun, the levels of genes were stable for up to $60 \mathrm{~min}$, after which their expressions were significantly reduced, especially for BIM-I treated HT1080 cells, in correlation with the cell death dynamics (Figure 1C). These data indicate that, except for jun, transcription of the genes does not occur, perhaps due to the increased signaling flux through the apoptosis process depriving transcriptional signaling and, or due to the repression of pre- and post-transcriptional mechanisms found during apoptosis (34-38). Our observations are also consistent with other TRAILinduced apoptosis studies investigating gene expressions in $\mathrm{HeLa}$ (35) and MCF7 (36) cells.

Interestingly, jun levels showed an initial decrease during the first $20 \mathrm{~min}$ and then increased and stabilized after $120 \mathrm{~min}$. This pattern indicates jun may evade the global transcriptional repression and play a role during apoptosis. Such behavior has been previously observed for other genes, in particular, genes translated through internal ribosome entry site (IRES)-mediated translation, which is known to occur during apoptosis after TRAIL stimulation of MCF7 cells $(36,39)$. Notably, the presence of IRESs in jun transcriptional machinery has also been previously shown (40). Nevertheless, further investigation is required to define the exact role of jun during TRAIL and BIM-I mediated apoptosis.

Overall, the experiments demonstrate that the enhancement of cell death of BIM-I pre-treated TRAIL-stimulated cancer occurs through apoptosis.

\section{IDENTIFICATION OF SPECIFIC PKC ISOFORM TARGET FOR ENHANCED CELL DEATH}

Although we have demonstrated that $\mathrm{PKC}$ is a key target to enhance apoptosis in TRAIL-resistant cancer cells, it is unknown which PKC family isoform, among the 10 major members $(\alpha, \beta, \gamma, \delta, \varepsilon, \mathrm{l}$, $\theta, \eta, \zeta$, and $\mu$ ), is a crucial single target. To investigate this, we first 
A Monitoring cell death with/without PKC inhibitor (BIM-I) + TRAIL stimulation

\begin{tabular}{|c|c|c|c|c|}
\hline & \multicolumn{2}{|c|}{ Control } & \multicolumn{2}{c|}{ Test } \\
\hline $\begin{array}{c}\text { TRAIL } \\
1000 \mathrm{ng} / \mathrm{mL}\end{array}$ & - & - & + & + \\
\hline $\begin{array}{c}\mathrm{BIM}-\mathrm{I} \\
10 \mu \mathrm{M}\end{array}$ & - & + & - & + \\
\hline $\begin{array}{c}\mathrm{HT} 1080 \\
\text { cells }\end{array}$ & & & & \\
& & & & \\
\hline Cell death & & & Observable & Significant \\
\hline
\end{tabular}
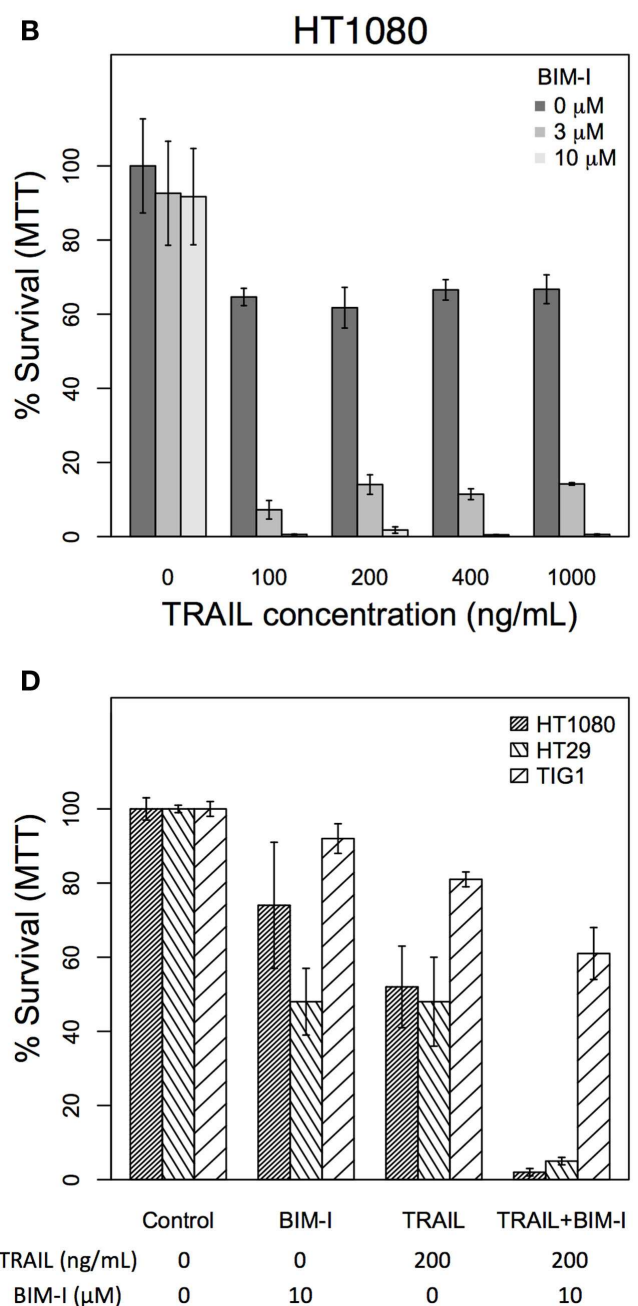

FIGURE 1 |The effect of TRAIL and PKC inhibitor (BIM-I) on cancer (HT1080 and HT29) and normal (TIG-1 and MRC-5) cells. (A) Phase contrast microscopic images of HT1080 cells in the presence or absence of TRAIL (1000 ng/mL) and/or BIM $(10 \mu \mathrm{M})$. Living cells appear as adherent cells, while dead cells float in the dish and are highlighted in white. (B) TRAIL and BIM-I dosage-dependent cell survival (MTT assay) rates of HT1080 cells $\left(1 \times 10^{5}\right)$, $24 \mathrm{~h}$ after treatment (TRAIL: $0,100,200$, 400, $1000 \mathrm{ng} / \mathrm{mL}, \mathrm{BIM}-\mathrm{I}: 0,3,10 \mu \mathrm{M})$. (C) Cell viability (trypan blue assay) of $\mathrm{HT} 1080$ cells $\left(3 \times 10^{5}\right)$ at $\mathrm{O}$ (no stimulation) and at $1,3,12,24 \mathrm{~h}$ after
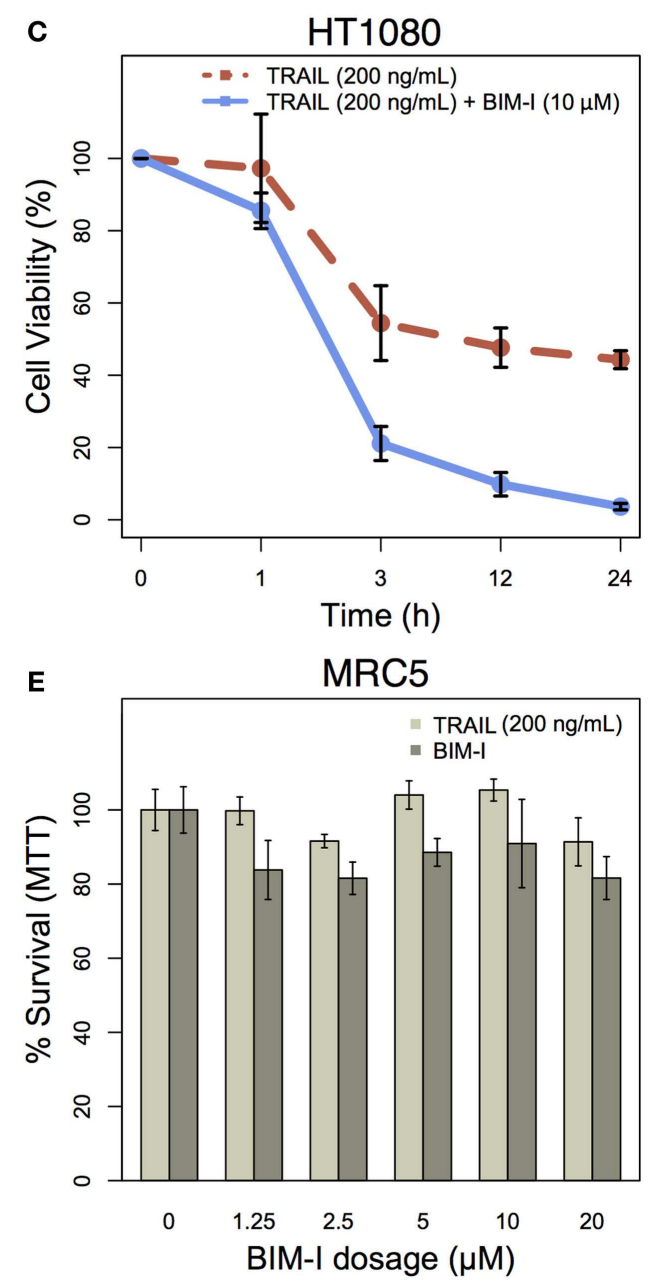

treatment (TRAIL: $200 \mathrm{ng} / \mathrm{mL}$, BIM-I: $10 \mu \mathrm{M})$. (D) Cell survival (MTT assay) rates of HT1080 $\left(1 \times 10^{5}\right)$, HT29 $\left(1.5 \times 10^{5}\right)$ cancer cells, and TIG-1 $\left(2 \times 10^{5}\right)$ normal cells were observed $24 \mathrm{~h}$ after treatment in the presence of TRAIL $(200 \mathrm{ng} / \mathrm{mL})$ or BIM-I $(10 \mu \mathrm{M})$, or both, compared to unstimulated cells (control). (E) BIM-I dosage-dependent $(0,1.25,2.5,5$, $10,20 \mu \mathrm{M})$ cell survival rates of MRC-5 $\left(0.5 \times 10^{5}\right)$ normal cells after TRAIL stimulation $(200 \mathrm{ng} / \mathrm{mL})$ were obtained through MTT assay after $24 \mathrm{~h}$. Average cell viability is shown in percentage for $n=3$ independent experiments. Error bars indicate mean values $\pm S D$. 

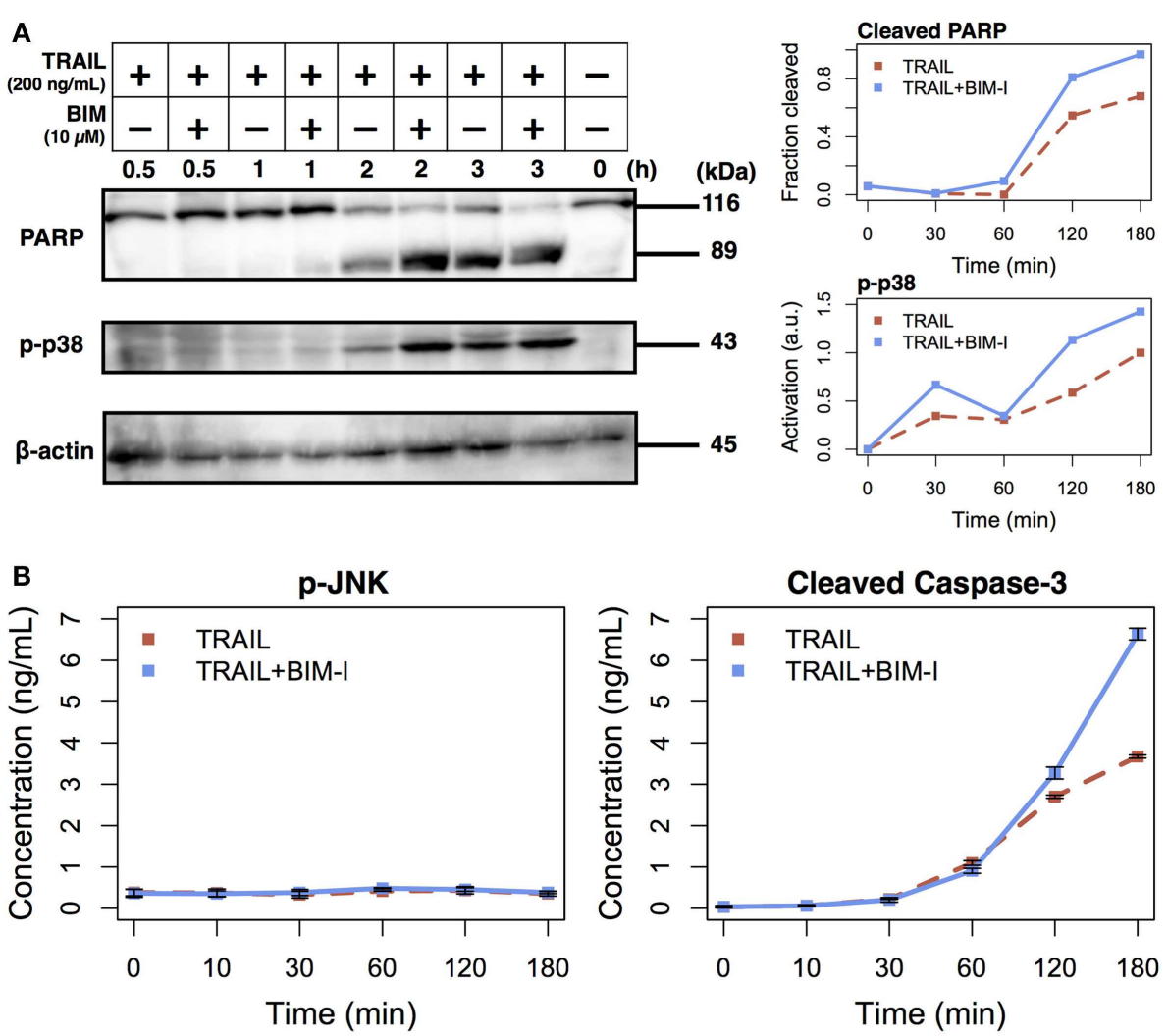

C

TRAIL

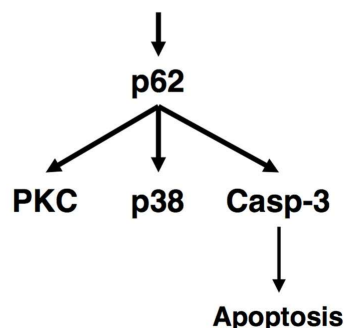

TRAIL

+ BIM-I
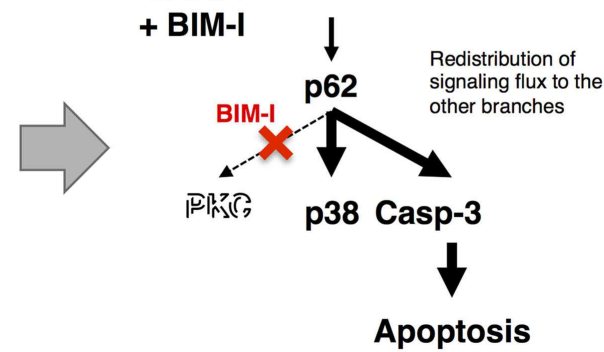

Signaling Flux Redistribution after PKC inhibition

FIGURE 2 | Enhancement of apoptotic signaling molecules in the presence of BIM-I in TRAIL-stimulated HT1080 cells. (A) Cleavage of PARP, phosphorylation of $\mathrm{p} 38$, and concentration of $\beta$-actin were determined by western blotting at $0,30,60,120$, and $180 \mathrm{~min}$ after TRAIL stimulation $(200 \mathrm{ng} / \mathrm{mL})$ of HT1080 cells in absence or presence of BIM-I $(10 \mu \mathrm{M})$. Right panels represent the quantification of fraction of cleaved PARP (top, cleaved PARP/total PARP for each time point) and p38 activation (bottom, relative to maximum value of TRAIL stimulation without BIM-I) using ImageJ (http://imagej.net). (B) Phosphorylation of JNK and levels of cleaved caspase-3 protein were measured by ELISA at $0,10,30,60,120$, and $180 \mathrm{~min}$ after TRAIL stimulation $(200 \mathrm{ng} / \mathrm{mL})$ of HT1080 cells in the absence or presence of BIM-I $(10 \mu \mathrm{M})$. Error bars indicate mean values $\pm \mathrm{SD}$ for $n=3$ independent experiments. (C) Schematic representing the mechanism of signaling flux redistribution at p62 pathway junction toward p38 and caspase-3 signaling branches when PKC is inhibited. measured the mRNA expressions of all 10 isoforms (the sequence of primers are available in Table 1) in unstimulated HT1080 cells using qRT-PCR.

We observed the gene expressions of four PKC isoforms $(\alpha, \delta, \varepsilon$, and $\iota$ ) were noticeably elevated, indicating that these isoforms may be crucial targets (Figure 4A). To investigate the effect of suppressing each of the four isoforms in TRAIL-stimulated HT1080 cells, we next performed siRNA-mediated PKC $(\alpha, \delta, \varepsilon$, and $\iota)$ KDs. The effect of each PKC KD was first confirmed after $24 \mathrm{~h}$ (Figure 4B). Consequently, we investigated cell viability by trypan blue for each of the four PKC KD conditions with and without TRAIL stimulation $(200 \mathrm{ng} / \mathrm{mL})$. Notably, PKC $\delta \mathrm{KD}$ produced the most significant cell death of approximately $83 \%$ after $3 \mathrm{~h}$ (Figure 4C). Note that this result is almost identical to TRAIL-stimulated HT1080 

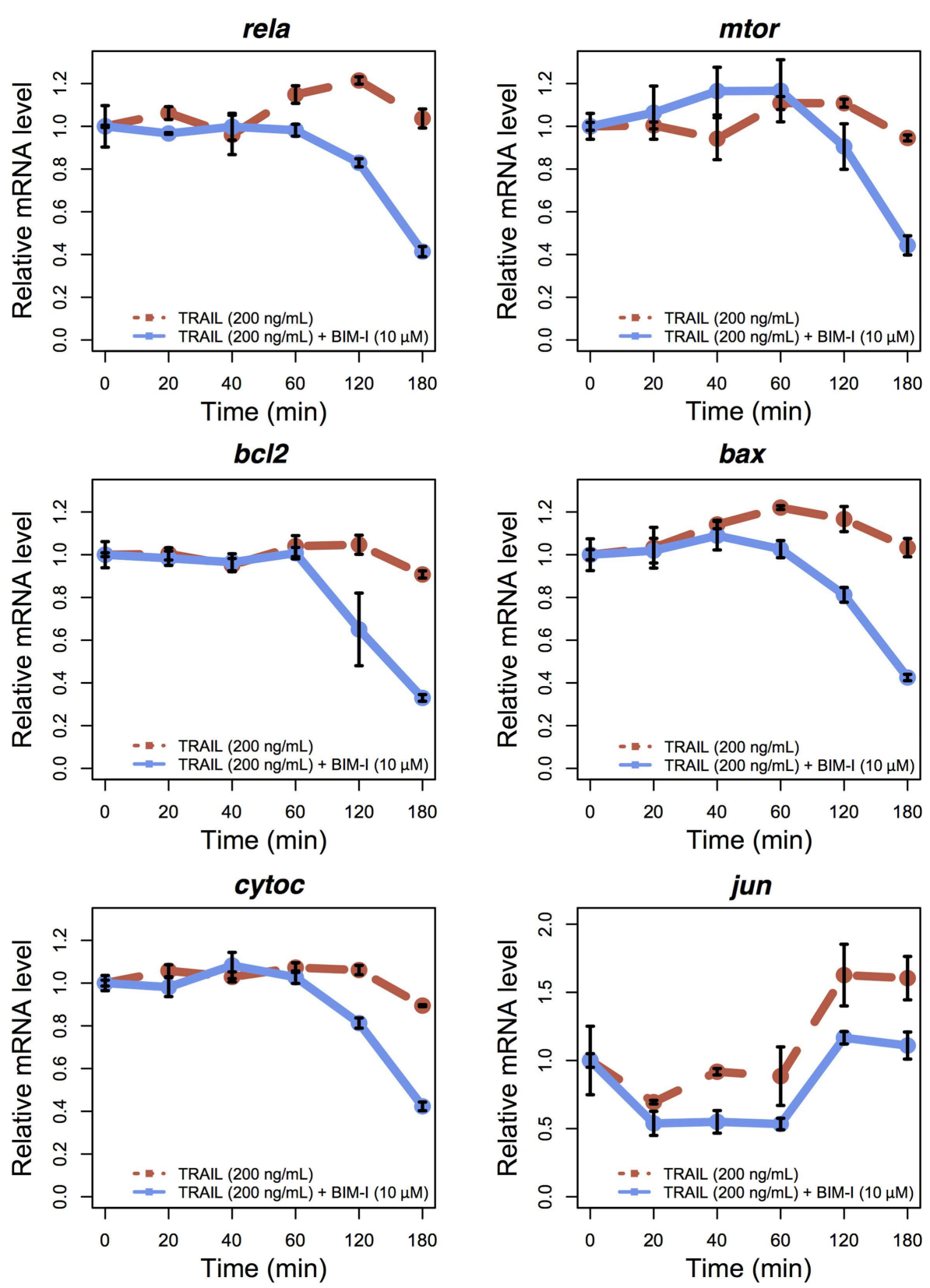

FIGURE 3 | Temporal relative mRNA expression in TRAIL and BIM-I treated HT1080 cells. Temporal expression profiles of

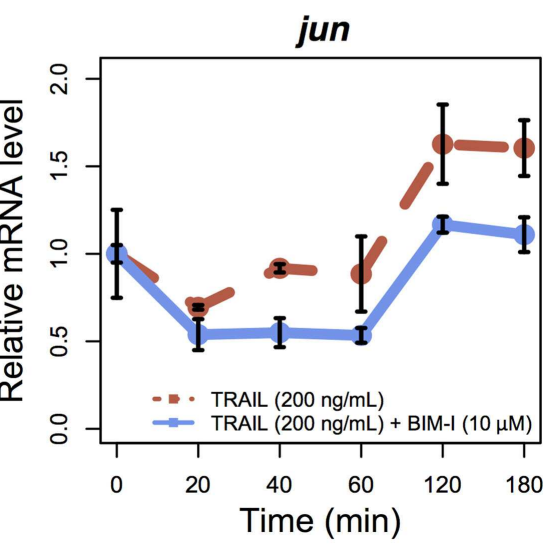

anti-apoptotic (rela, mtor, bcl2, and jun) and pro-apoptotic (bax and cytoc) genes in HT1080 cells at $0,20,40,60,120$, and 180 min after

TRAIL stimulation $(200 \mathrm{ng} / \mathrm{mL}$ ) without (red line) or with (blue line)

pre-treatment of BIM-I (10 $\mu \mathrm{M}) 30$ min prior to TRAIL stimulation. Note that jun can also be considered as a pro-apoptotic gene (40). Reported values are the mean expression values $(n=3$ independent experiments) relative to time 0 of each condition. Error bars indicate mean values $\pm S D$

pre-treated with BIM-I at $3 \mathrm{~h}$ (Figure 1C). Thus, our experiments reveal that $\mathrm{PKC} \delta$ is the optimal single target for enhancing cancer apoptosis in TRAIL-based therapy.

\section{DISCUSSION}

TRAIL, a proinflammatory cytokine produced by the mammalian immune system, is known to induce apoptosis in cancer cells while leaving non-diseased cells largely unharmed $(41,42)$. Hence, there has been intense interest in using TRAIL has a therapeutic target to treat cancers $(43,44)$. However, not all cancers respond to TRAIL $(45,46)$.

Previously, we investigated the TRAIL-resistant mechanism in HT1080 cells using a computational model (1). We predicted that the suppression of a novel pro-survival molecule would result in significant enhancement of apoptosis through signaling flux redistribution (22). PPI database search indicated that the 

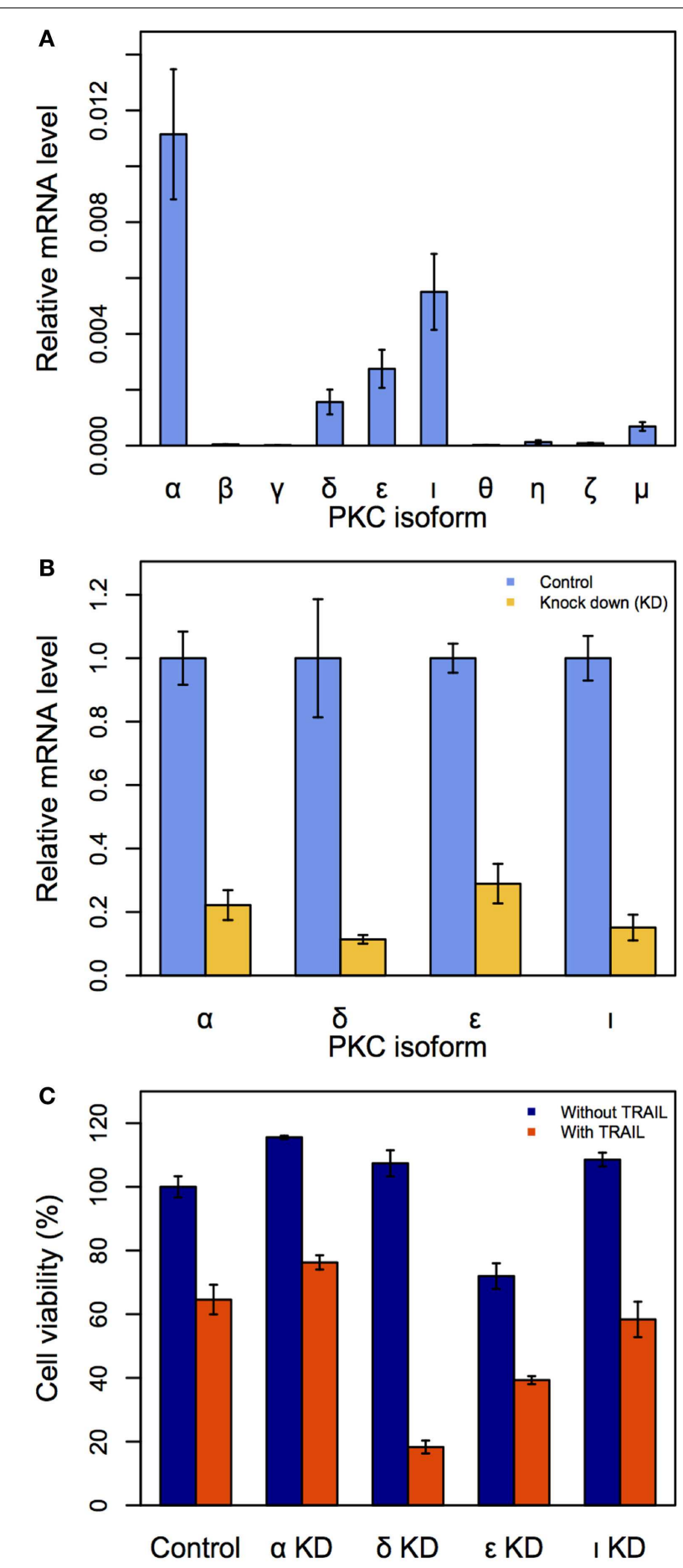

FIGURE 4 | Identification of the specific PKC isoform target to enhance apoptosis in HT1080 cells. (A) Relative mRNA expressions of 10 PKC isoforms in HT1080 unstimulated cells. (B) Effect of siRNA knock-down (KD) for $P K C \alpha, P K C \mathrm{l}, P K C \varepsilon$, and $P K C \delta$. HT1080 cells were incubated in the presence of each PKC isoform siRNA $(50 \mu \mathrm{M})$ for $24 \mathrm{~h}$. Relative mRNA expressions of four PKC isoforms are measured by qRT-PCR. (C) Cell viability assay (trypan blue) of HT1080 cells incubated in the presence of PKC isoforms siRNA $(50 \mu \mathrm{M})$ for $3 \mathrm{~h}$. Error bars indicate mean values $\pm \mathrm{SD}$. for $n=3$ independent experiments. pro-survival molecule is a member of PKC. To experimentally validate this result, in this article, we investigated the effects of two TRAIL-resistant cancer cells to PKC inhibition.

First, using different doses of PKC inhibitor BIM-I together with various levels of TRAIL stimulation, we observed approximately 99 and 95\% cell death occurred for HT1080 and HT29 cells, respectively (Figure 1). Notably, the effect on control TIG-1 and MRC-5 cells were less significant, at approximately 40 and $20 \%$ cell death, respectively.

Second, to confirm the mechanism for cell death is through apoptosis, we measured the activations of PARP and caspase-3 over $3 \mathrm{~h}$ in TRAIL-stimulated HT1080 cells untreated and treated with BIM-I, and compared with activations of p38 and JNK. We found that PARP, caspase-3 cleavages and p38 phosphorylation were significantly enhanced in BIM-I treated cells (Figure 2), while JNK activity was very low. These results are in consistency with the previous prediction of our computational model (1). We also investigated the expressions of major pro- and antiapoptotic genes, and found them to be mostly repressed at their transcription levels, especially after $1 \mathrm{~h}$ for BIM-I treated cells (Figure 3).

Third, to identify the crucial PKC family member for single specific target, we investigated the mRNA expressions of all 10 major isoforms in HT1080 cells. We selected the top four significantly expressed isoforms for developing siRNA KDs, and subsequent experiments demonstrated that PKC $\delta$ is a key target for enhancing cell death in TRAIL-resistant HT1080 cells (Figure 4).

It is worthy to mention other previous works that have studied PKC in different cancer types (47-50). Although these works have demonstrated the importance of $\mathrm{PKC}$, the investigations were performed in different cell lines or stimulations. In this work, however, we focused mainly on HT1080 and limitedly on HT29 cells. In addition, we bring to the attention the power of using multidisciplinary research to systemically identify a key target that can be experimentally tested. Therefore, to our knowledge, this is the first time the usefulness of a computational model is shown to identify a consistent and key target for regulating TRAIL-resistance. In summary, our work provides further evidence for the utility of systemic approaches in providing effective treatment strategies to tackle complex diseases.

\section{AUTHOR CONTRIBUTIONS}

Kentaro Hayashi and Kumar Selvarajoo conceptualized and designed the study. Kentaro Hayashi and Sho Tabata performed the wet lab experiments. Masaru Tomita and Kumar Selvarajoo provided cells, reagents, and discussions. Kentaro Hayashi, Vincent Piras, and Kumar Selvarajoo wrote the article. All authors read and approved the final manuscript.

\section{ACKNOWLEDGMENTS}

We thank Mitsuhiro Kitagawa, Tomas Gomes Cardoso, Kiyotoshi Sato, and Akio Kanai for experimental support and critical suggestions. This work was supported by the Japan Society for the Promotion of Science (JSPS) Grants-in-Aid for Scientific Research J13108 (Kumar Selvarajoo), Scientific Research F13804 (Kentaro Hayashi), and Tsuruoka City, Yamagata Prefecture. 


\section{REFERENCES}

1. Piras V, Hayashi K, Tomita M, Selvarajoo K. Enhancing apoptosis in TRAILresistant cancer cells using fundamental response rules. Sci Rep (2011) 1:144. doi:10.1038/srep00144

2. Grivennikov SI, Greten FR, Karin M. Immunity, inflammation, and cancer. Cell (2010) 140:883-99. doi:10.1016/j.cell.2010.01.025

3. Swann JB, Vesely MD, Silva A, Sharkey J, Akira S, Schreiber RD, et al. Demonstration of inflammation-induced cancer and cancer immunoediting during primary tumorigenesis. Proc Natl Acad Sci U S A (2008) 105:652-6. doi:10.1073/pnas.0708594105

4. Balkwill F. TNF-alpha in promotion and progression of cancer. Cancer Metastasis Rev (2006) 25:409-16. doi:10.1007/s10555-006-9005-3

5. Mantovani A, Sozzani S, Locati M, Allavena P, Sica A. Macrophage polarization: tumor-associated macrophages as a paradigm for polarized M2 mononuclear phagocytes. Trends Immunol (2002) 23:549-55. doi:10.1016/S1471-4906(02) 02302-5

6. Pitti RM, Marsters SA, Ruppert S, Donahue CJ, Moore A, Ashkenazi A. Induction of apoptosis by Apo-2 ligand, a new member of the tumor necrosis factor cytokine family. J Biol Chem (1996) 271:12687-90. doi:10.1074/jbc.271.22. 12687

7. Wiley SR, Schooley K, Smolak PJ, Din WS, Huang CP, Nicholl JK, et al. Identification and characterization of a new member of the TNF family that induces apoptosis. Immunity (1995) 3:673-82. doi:10.1016/1074-7613(95) 90057-8

8. Zhang XD, Nguyen T, Thomas WD, Sanders JE, Hersey P. Mechanisms of resistance of normal cells to TRAIL induced apoptosis vary between different cell types. FEBS Lett (2000) 482:193-9. doi:10.1016/S0014-5793(00)02042-1

9. Jo M, Kim TH, Seol DW, Esplen JE, Dorko K, Billiar TR, et al. Apoptosis induced in normal human hepatocytes by tumor necrosis factor-related apoptosisinducing ligand. Nat Med (2000) 6:564-7. doi:10.1038/75045

10. Keane MM, Ettenberg SA, Nau MM, Russell EK, Lipkowitz S. Chemotherapy augments TRAIL-induced apoptosis in breast cell lines. Cancer Res (1999) 59:734-41.

11. Eggert A, Grotzer MA, Zuzak TJ, Wiewrodt BR, Ho R, Ikegaki N, et al. Resistance to tumor necrosis factor-related apoptosis-inducing ligand (TRAIL)-induced apoptosis in neuroblastoma cells correlates with a loss of caspase-8 expression. Cancer Res (2001) 61:1314-9.

12. Trauzold A, Siegmund D, Schniewind B, Sipos B, Egberts J, Zorenkov D, et al. TRAIL promotes metastasis of human pancreatic ductal adenocarcinoma. Oncogene (2006) 25:7434-9. doi:10.1038/sj.onc.1209719

13. Hao C, Beguinot F, Condorelli G, Trencia A, Van Meir EG, Yong VW, et al. Induction and intracellular regulation of tumor necrosis factor-related apoptosisinducing ligand (TRAIL) mediated apotosis in human malignant glioma cells. Cancer Res (2001) 61:1162-70.

14. Hoffmann A, Levchenko A, Scott ML, Baltimore D. The IkappaB-NF-kappaB signaling module: temporal control and selective gene activation. Science (2002) 298:1241-5. doi:10.1126/science. 1071914

15. Vance W, Arkin A, Ross J. Determination of causal connectivities of species in reaction networks. Proc Natl Acad Sci U S A (2002) 99:5816-21. doi:10.1073/ pnas.022049699

16. Birtwistle MR, Hatakeyama M, Yumoto N, Ogunnaike BA, Hoek JB, Kholodenko BN. Ligand-dependent responses of the ErbB signaling network: experimental and modeling analyses. Mol Syst Biol (2007) 3:144. doi:10.1038/msb4100188

17. Yeo ZX, Wong ST, Arjunan SN, Piras V, Tomita M, Selvarajoo K, et al. Sequential logic model deciphers dynamic transcriptional control of gene expressions. PLoS One (2007) 2:e776. doi:10.1371/journal.pone.0000776

18. Selvarajoo K, Tomita M. Physical laws shape biology. Science (2013) 339:646. doi:10.1126/science.339.6120.646-a

19. Selvarajoo K. Understanding multimodal biological decisions from single cell and population dynamics. Wiley Interdiscip Rev Syst Biol Med (2012) 4:385-99. doi:10.1002/wsbm.1175

20. Selvarajoo K. Parameter-less approaches for interpreting dynamic cellular response. J Biol Eng (2014) 8:23. doi:10.1186/1754-1611-8-23

21. Piras V, Tomita M, Selvarajoo K. Transcriptome-wide variability in single embryonic development cells. Sci Rep (2014) 4:7137. doi:10.1038/srep07137

22. Selvarajoo K, Takada Y, Gohda J, Helmy M, Akira S, Tomita M, et al. Signaling flux redistribution at toll-like receptor pathway junctions. PLoS One (2008) 3:e3430. doi:10.1371/journal.pone.0003430
23. Selvarajoo K, Tomita M, Tsuchiya M. Can complex cellular processes be governed by simple linear rules? J Bioinform Comput Biol (2009) 7:243-68. doi:10.1142/S0219720009003947

24. Selvarajoo K. Macroscopic law of conservation revealed in the population dynamics of toll-like receptor signaling. Cell Commun Signal (2011) 9:9. doi:10.1186/1478-811X-9-9

25. Selvarajoo K. Discovering differential activation machinery of the toll-like receptor 4 signaling pathways in MyD88 knockouts. FEBS Lett (2006) 580:1457-64. doi:10.1016/j.febslet.2006.01.046

26. Helmy M, Gohda J, Inoue J-I, Tomita M, Tsuchiya M, Selvarajoo K. Predicting novel features of toll-like receptor 3 signaling in macrophages. PLoS One (2009) 4:e4661. doi:10.1371/journal.pone.0004661

27. Hayashi K, Piras V, Tabata S, Tomita M, Selvarajoo K. A systems biology approach to suppress TNF-induced proinflammatory gene expressions. Cell Commun Signal (2013) 11:84. doi:10.1186/1478-811X-11-84

28. Selvarajoo K, Tsuchiya M. Systematic determination of biological network topology: non-integral connectivity method (NICM). In: Choi S, editor. Introduction to System Biology. Totawa, NJ: The Humana Press Inc (2007). p. 449-71.

29. Tan P, Selvarajoo K. Modelling of Biochemical Pathways. US Patent No. 20030113761 (2003).

30. Varfolomeev E, Maecker H, Sharp D, Lawrence D, Renz M, Vucic D, et al. Molecular determinants of kinase pathway activation by Apo2 ligand/tumor necrosis factor-related apoptosis-inducing ligand. J Biol Chem (2005) 280:40599-608. doi:10.1074/jbc.M509560200

31. Toullec D, Pianetti P, Coste H, Bellevergue P, Grand-Perret T, Ajakane M, et al. The bisindolylmaleimide GF $109203 \mathrm{X}$ is a potent and selective inhibitor of protein kinase C. J Biol Chem (1991) 266:15771-81.

32. Davis PD, Hill CH, Keech E, Lawton G, Nixon JS, Sedgwick AD, et al. Potent selective inhibitors of protein kinase C. FEBS Lett (1989) 259:61-3. doi:10.1016/ 0014-5793(89)81494-2

33. Wilkinson SE, Parker PJ, Nixon JS. Isoenzyme specificity of bisindolylmaleimides, selective inhibitors of protein kinase C. Biochem J (1993) 294:335-7.

34. Del Prete MJ, Robles MS, Guáo A, Martínez-A C, Izquierdo M, Garcia-Sanz JA. Degradation of cellular mRNA is a general early apoptosis-induced event. FASEB J (2002) 16:2003-5. doi:10.1096/fj.02-0392fje

35. Bushell M, Stoneley M, Sarnow P, Willis AE. Translation inhibition during the induction of apoptosis: RNA or protein degradation? Biochem Soc Trans (2004) 32:606-10. doi:10.1042/BST0320606

36. Bushell M, Stoneley M, Kong YW, Hamilton TL, Spriggs KA, Dobbyn HC, et al. Polypyrimidine tract binding protein regulates IRES-mediated gene expression during apoptosis. Mol Cell (2006) 23:401-12. doi:10.1016/j.molcel. 2006.06.012

37. Thomas MP, Lieberman J. Live or let die: posttranscriptional gene regulation in cell stress and cell death. Immunol Rev (2013) 253:237-52. doi:10.1111/imr. 12052

38. Elmore S. Apoptosis: a review of programmed cell death. Toxicol Pathol (2007) 35:495-516. doi:10.1080/01926230701320337

39. Spriggs KA, Bushell M, Mitchell SA, Willis AE. Internal ribosome entry segmentmediated translation during apoptosis: the role of IRES-trans-acting factors. Cell Death Differ (2005) 12:585-91. doi:10.1038/sj.cdd.4401642

40. Blau L, Knirsh R, Ben-Dror I, Oren S, Kuphal S, Hau P, et al. Aberrant expression of c-Jun in glioblastoma by internal ribosome entry site (IRES)mediated translational activation. Proc Natl Acad Sci US A (2012) 109:E2875-84. doi:10.1073/pnas.1203659109

41. Johnstone RW, Frew AJ, Smyth MJ. The TRAIL apoptotic pathway in cancer onset, progression and therapy. Nat Rev Cancer (2008) 8:782-98. doi:10.1038/ $\operatorname{nrc} 2465$

42. Kim K, Fisher MJ, Xu SQ, el-Deiry WS. Molecular determinants of response to TRAIL in killing of normal and cancer cells. Clin Cancer Res (2000) 6:335-46.

43. Smyth MJ, Takeda K, Hayakawa Y, Peschon JJ, van den Brink MRM, Yagita H. Nature's TRAIL - on a path to cancer immunotherapy. Immunity (2003) 18:1-6. doi:10.1016/S1074-7613(02)00502-2

44. Wang S, El-Deiry WS. TRAIL and apoptosis induction by TNF-family death receptors. Oncogene (2003) 22:8628-33. doi:10.1038/sj.onc.1207232

45. Ehrhardt H, Fulda S, Schmid I, Hiscott J, Debatin K-M, Jeremias I. TRAIL induced survival and proliferation in cancer cells resistant towards TRAILinduced apoptosis mediated by NF-kappaB. Oncogene (2003) 22:3842-52. doi:10.1038/sj.onc. 1206520 
46. Khanbolooki S, Nawrocki ST, Arumugam T, Andtbacka R, Pino MS, Kurzrock R, et al. Nuclear factor-kappaB maintains TRAIL resistance in human pancreatic cancer cells. Mol Cancer Ther (2006) 5:2251-60. doi:10.1158/1535-7163.MCT06-0075

47. Harper N, Hughes MA, Farrow SN, Cohen GM, MacFarlane M. Protein kinase $\mathrm{C}$ modulates tumor necrosis factor-related apoptosis-inducing ligand-induced apoptosis by targeting the apical events of death receptor signaling. J Biol Chem (2003) 278:44338-47. doi:10.1074/jbc.M307376200

48. Gatsinzi T, Ivanova EV, Iverfeldt K. TRAIL resistance in human neuroblastoma SK-N-AS cells is dependent on protein kinase $\mathrm{C}$ and involves inhibition of caspase-3 proteolytic processing. J Neurooncol (2012) 109:503-12. doi:10.1007/s11060-012-0932-2

49. Okhrimenko H, Lu W, Xiang C, Hamburger N, Kazimirsky G, Brodie C. Protein kinase C-epsilon regulates the apoptosis and survival of glioma cells. Cancer Res (2005) 65:7301-9. doi:10.1158/0008-5472.CAN-05-1064

50. Shankar E, Sivaprasad U, Basu A. Protein kinase C epsilon confers resistance of MCF-7 cells to TRAIL by Akt-dependent activation of Hdm2 and downregulation of p53. Oncogene (2008) 27:3957-66. doi:10.1038/onc.2008.39
Conflict of Interest Statement: The authors declare that the research was conducted in the absence of any commercial or financial relationships that could be construed as a potential conflict of interest.

Received: 25 June 2014; accepted: 08 December 2014; published online: 05 January 2015.

Citation: Hayashi K, Tabata S, Piras V, Tomita M and Selvarajoo K (2015) Systems biology strategy reveals PKCS is key for sensitizing TRAIL-resistant human fibrosarcoma. Front. Immunol. 5:659. doi: 10.3389/fimmu.2014.00659

This article was submitted to Tumor Immunity, a section of the journal Frontiers in Immunology.

Copyright (c) 2015 Hayashi, Tabata, Piras, Tomita and Selvarajoo. This is an openaccess article distributed under the terms of the Creative Commons Attribution License (CC BY). The use, distribution or reproduction in other forums is permitted, provided the original author(s) or licensor are credited and that the original publication in this journal is cited, in accordance with accepted academic practice. No use, distribution or reproduction is permitted which does not comply with these terms. 